\title{
KADERISASI PADA MASA RASULULLAH
}

\author{
Imam Taufik Alkhotob \\ imamtaufik@stidnatsir.ac.id \\ Program Studi Komunikasi Penyiaran Islam \\ Sekolah Tinggi Ilmu Da'wah Mohammad Natsir, Indonesia
}

\begin{abstract}
ABSTRAK
Tujuan Penelitian: Untuk mengetahui kaderisasi pada masa Rasulullah. Metode Penelitian: Kualitatif. Hasil Penelitian: Kaderisasi adalah proses yang sangat penting dalam sebuah gerakan da'wah. Karena itulah Rasulullah Saw. sangat memperhatikan proses kaderisasi ini. Untuk mengkaji proses kaderisasi dalam da'wah yang dilakukan oleh Rasulullah Saw. itu lah kajian ini dilakukan. Ditemukan bahwa proses kaderisasi Rasulullah bersifat menyeluruh terhadap semua sahabat. Sehingga dapat disimpulkan bahwa seluruh sahabat Rasulullah Saw berhasil dikader menjadi para penerus gerakan da'wah Rasulullah Saw. Yang lebih menakjubkan lagi, masing-masing para sahabat memiliki kemampuan sendiri-sendiri dalam berbagai bidang. Ada yang ahli politik, ahli ekonomi, abli fiqih, abli strategi perang dan lainnya.
\end{abstract}

Kata Kunci: Da’wah, Kader, Kaderisasi.

\section{PENDAHULUAN}

Kaderisasi atau pengkaderan memiliki arti sebuah proses, cara, atau perbuatan mendidik atau membentuk seseorang menjadi kader ${ }^{1}$. Proses kaderisasi tidak selalu identik dengan lingkup organisasi atau suatu kelembagaan formal. Pada intinya, proses kaderisasi dapat berjalan manakala terdapat seseorang yang mengkader, materi pengkaderan, dan objek yang dikader. Ketika ketiga unsur dasar ini ada, maka proses pengkaderan dapat berjalan meskipun dalam bentuk yang sederhana. Dalam perkembangannya, tentu saja setiap orang maupun kelompok memiliki hak untuk

\footnotetext{
${ }^{1}$ Wikipedia, http://id.wikipedia.org/wiki/Kader
} 
mengembangkan, menambah, dan melakukan improvisasi terhadap bentuk, model atau sistem pengkaderan yang dijalankan.

Jika kita merujuk kepada sirah nabawiyah Rasulullah Muhammad shallallâhu'alaibi wasallam, maka beliaupun juga melakukan proses pengkaderan sebagaimana dijelaskan di atas.

Dalam proses pengkaderan, Rasulullah adalah orang yang berperan sebagai pengkader. Dialah ujung tombak utama proses pengkaderan yang terjadi pada masa beliau. Sementara itu, materi pengkaderan yang disampaikan beliau adalah risalah Islam atau syari'at Islam yang bersumber dari wahyu Allah Tabaraka Wata'âlâ. Adapun objek kaderisasi atau "kader" yang dibina adalah orang-orang yang berislam pada masa Nabi dan wafat dalam keadaan Islam pula. Merekalah yang disebut-sebut oleh para ulama dengan istilah; ash shahâbat (para sahabat Nabi). ${ }^{3}$ Para sahabatlah kader-kader Rasulullah yang membantu dalam menjalankan misi risalah Islam untuk disampaikan kepada seluruh manusia tanpa terkecuali. Kita dapat pula menyebut para sahabat sebagai kader da'wah karena pada prinsipnya, apa yang dilakukan oleh mereka adalah mendakwahkan ajaran Islam sesuai dengan apa yang dicontohkan oleh Baginda Rasul.

\section{HASIL DAN DISKUSI}

\section{A. Bentuk Pengkaderan Rasulullah}

Dimuka telah penulis singgung tentang bentuk pengkaderan Nabi secara umum dilakukan dengan bentuk yang alami dan terseleksi

${ }^{22}$ Yang dimaksud wahyu disini meliputi al Qur'an dan As Sunnah. Hal itu berdasarkan prinsip akidah bahwasannya apa yang datang dari Rasulullah baik berupa perkataan dan perbuatan semuanya berdasarkan petunjuk dari wahyu Allah sebagaimana tersebut dalam surah An Najm: 3-4.

${ }^{3}$ Menurut penjelasan Imam Ibnu Katsir, definisi yang disebutkan oleh mayoritas para ulama' baik khalaf maupun salaf adalah sebagai berikut;

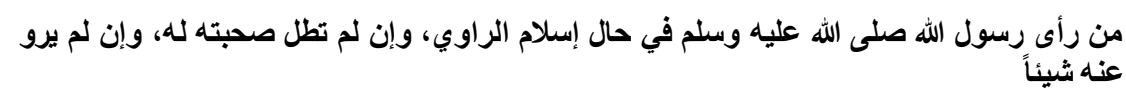

( "Orang yang melihat Rasulullah Shallallahu'alaihi Wasallam dalam keadaan Islam, yang meriwayatkan sabda Nabi. Meskipun ia bertemu Rasulullah tidak dalam tempo yang lama, atau Rasulullah belum pernah melihat ia sama sekali”) .Lihat, Abi al Fida' Isma'il ibn Katsir, Al Ba'its Al Hatsits Fikhtishari 'Ulumil Hadits, Maktabah As Syamilah, Jilid 1, hal. 24 
secara alami pula. Nabi tidak melakukan pengkaderan secara formal dan menggunakan metode modern seperti yang ada pada zaman ini. Namun demikian, apa yang Rasulullah lakukan ternyata lebih mampu memberikan hasil yang luarbiasa kepada orang-orang yang dibina dan dikader oleh beliau. Hal ini membuktikan bahwa Rasulullah sangat serius dalam mengkader para sahabat. Apalagi beliau sadar bahwa menegakkan Islam berarti harus siap untuk berkorban kapanpun dan dimanapun.

Para sahabat sebagai kader langsung yang dibina oleh Rasulullah telah menampakkan kegemilangannya dalam membersamai Rasul untuk menyebarkan Islam. Oleh sebab itulah Rasulullah menyebut masa itu dengan kharirun nas (manusiaterbaik) atau khairul qurun (zaman terbaik/keemasan), sebagaimana tersebut dalam hadits berikut ini;

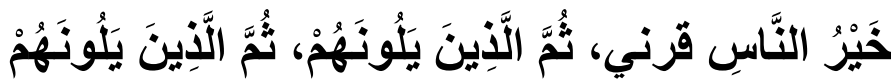

Artinya: "Sebaik-baik manusia adalah yang ada pada zamanku, kemudian setelah mereka, kemudian setelah mereka" (HR. Bukhari dan Muslim) ${ }^{4}$

Tidak hanya itu, al Qur'an mensifati mereka dengan khairu ummah.

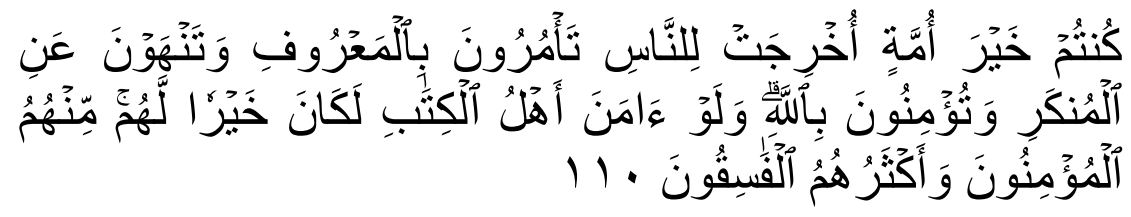

Artinya: "Kamu adalah umat yang terbaik yang dilabirkan untuk manusia, menyuruh kepada yang ma'ruf, dan mencegah dari yang munkar, dan beriman kepada Allah. Sekiranya abli kitab beriman, tentulah itu lebib baik bagi mereka, di antara mereka ada yang beriman, dan kebanyakan mereka adalah orang-orang yang fasik.." (QS. Ali Imran: 110)

Yang dimaksud khairu ummah pada ayat ini pertamakali disematkan kepada para sahabat karena ayat ini turun terkait dengan

${ }^{4}$ Muhammad bin Futuh al Humaidi, Al Jam'u Baina Sahîh Bukhâri wa Muslim, tahqiq. Dr. Ali Husain al Bawab, Beirut: Dâr al Nahr, 2002, Jilid 1, hal. 120 
sifat-sifat kehidupan mereka sebagaimana penjelasan Umar bin Khattab radhiyallâbu'anbu;

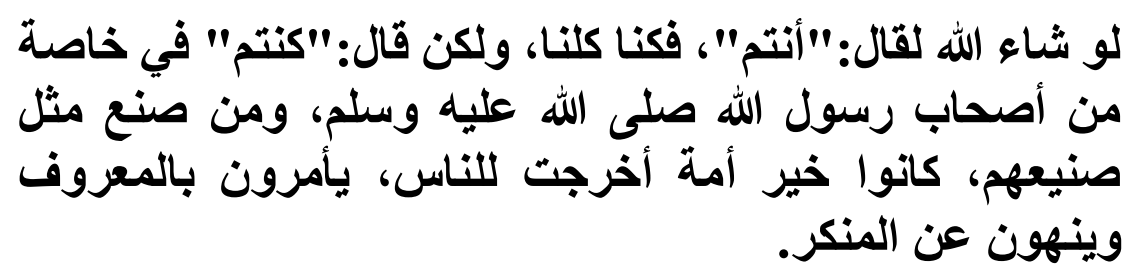

(Jika Allah berkehendak niscaya Dia telah mengatakan antum, yang termasuk semua kita. Akan tetapi Allah ta'ala hendak mengkhususkan kata kuntum hanya kepada para sahabat Nabi Muhammad SAW semata dan siapa yang melakukan seperti yang dilakukan oleh mereka saja, yakni menjadi sebaik-baik ummat yang dikeluarkan bagi manusia. $)^{5}$

Oleh sebab itu, salah seorang sahabat mulia Abdullah bin Mas'ud memberikan kesaksian sebagai berikut;

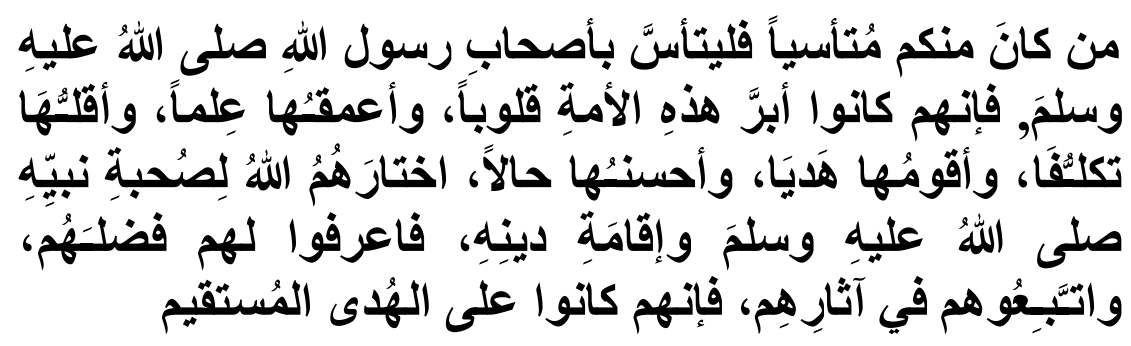

(Siapa saja yang mencari teladan, teladanilah para sahabat Rasulullah Shallallahu'alaihi Wasallam. Karena merekalah orang yang paling baik hatinya diantara umat ini, paling mendalam ilmu agamanya, umat yang paling sedikit dalam berlebihan-lebihan, paling lurus bimbingannya, paling baik keadaannya. Allah telah memilih mereka untuk mendampingi Nabi Shallallahu'alaihi Wasallam dan menegakkan agama-Nya. Kenalilah keutamaan mereka, dan ikutilah

${ }^{5}$ Abu Ja'far At Thabari, Jâmi' al Bayân fì Ta'wîl al Qur'ân, tahqiq. Ahmad Muhammad Syakir, Tt: Mu'assasah Al Risâlah, 2000, jilid 7, hal. 10 
jalan mereka. Karena mereka semua berada pada shiratal mustaqim (jalan yang lurus). ${ }^{6}$

Itulah para sahabat Nabi, sebagai generasi yang dibimbing langsung dalam pengkaderan Rasulullah.

\section{a. Materi Pengkaderan}

Jika kita ingin menggali bagaimana pengkaderan yang Rasulullah lakukan, maka kita dapat melihatnya secara umum melalui gerakan da'wah Nabi yang dilakukan sejak fase Makkah dan Madinah. Dari sisi materi pengkaderan, maka kita dapat melihat bahwa fase Makkah merupakan fase dimana Rasulullah lebih banyak menekankan aspek akidah dan penanaman pondasi keimanan secara kuat. Ayat-ayat yang turun pada fase ini juga berkaitan denga hal tersebut ${ }^{7}$. Pondasi keimanan menjadi penting karena ia merupakan pandangan hidup sekaligus landasan berpijak bagi setiap aktifitas hidup. Sementara itu, setiap amal yang tidak dibangun di atas prinsip iman, maka ia tidak akan memiliki faedah dan hanya menjadi kesiasiaan belaka.

Setelah masa hijrah ke Madinah berlangsung, maka materimateri syari'at Islam bertambah dan berkembang kepada aspek-aspek ibadah, mu'amalah, pemerintahan, ekonomi, adab dan akhlaq, kesehatan, dan lain-lain. Intinya, secara bertahap ajaran Islam mulia dijelaskan secara lengkap hingga tiba kesempurnaan ajaran Islam pada saat haji wada' berlangsung. ${ }^{8}$ Namun perlu diperhatikan bahwa pada

${ }^{6}$ Abu Abdillah Muhammad bin Ahmad bin Abi Bakar bin Farah al Qurthubi, Al Jâmi' li Ahkâm al Qur'ân, Jilid 1, hal. 60

${ }^{7}$ Dalam istilah ilmu al Qur'an, ayat-ayat Makkiyah adalah ayat-ayat yang turun sebelum hijrah meskipun itu di Madinah. Sementara Madaniyah adalah ayat-ayat yang turun setelah hijrah Nabi meskipun ayat itu turun di Makkah. Imam Az Zarkasyi mendefinisikan seperti ini;

و هو المشهور أن المكي ما نزل قبل الهجرة و إن كان بالمدينة والمدني ما نزل بعد الهجرة وإن كان بمكة

Lihat, Muhammad bin Abdullah bin Bahadur Al Zarkasyi, Al Burhân fì 'Ulûm al Qur'ân, tahqiq, Muhammad Abu Fahl Ibrahim, Beirut: Dâr al Ma'rifah, 1957, Jilid 1, hal. 188

8 Peristiwa Haji Wada' yang paling agung adalah ketika Allah menurunkan surah Al Ma'idah ayat ke 3. Ayat itu menjadi bukti bahwa risalah rasulullah telah betul-betul sempurna. Lihat, Aburrahman bin Nashir bin As Sa'di, Taisîr al Karîm al Rahmân fì Tafsîr Kalâm al Mannân, tahqiq. Abdurrahman bin Ma'al,Tt: Mu'assasah Al Risâlah, 2000, hal. 219 
fase ini, Rasulullah sama sekali tidak meninggalkan materi-materi akidah atau keimanan. Bahkan materi ini menjadi semakin matang dan diperhatikan sebagaimana materi-materi lainnya. Hal itu terlihat dari banyak hadits-hadits Nabi berbicara lebih rinci tentang hal-hal yang dilarang dalam akidah seperti; membangun masjid di atas kuburan, peristiwa dzatu anwat pada perang Hunain, larangan tathayyur, larangan mendatangi dukun, tukang sihir atau ahli peramal, peristiwa penghancuran berhala dzul khulasah setelah penaklukkan Makkah, dan lain-lain. Menurut hemat penulis hal ini menunjukkan keutamaan akidah jika dibandingkan dengan ilmu-ilmu lainnya. Oleh karena itu Syaikhul Islam Ibnu Taimiyah memberikan urutan pertama kepada ilmu akidah dalam klasifikasi ilmu. Beliau mengatakan;

"Ilmu itu ada lima; 1. Ilmu yang merupakan kehidupan bagi agama yaitu ilmu tauhid. 2. Ilmu yang merupakan santapan agama, yaitu ilmu tentang mempelajari makna-makna alQur'an dan hadits, 3. Ilmu yang merupakan obat agama, yaitu ilmu fatwa. Apabila suatu musibah (malapetaka) datang kepada seorang hamba, ia membutuhkan orang yang mampu menyembuhkannya dari musibah itu, sebagaimana dikatakan oleh Ibn Mas'ud. 4. Ilmu yang merupakan penyakit agama, yaitu ilmu kalam dan bid'ah. Dan 5. Ilmu yang merupakan kebinasaan bagi agama, yaitu ilmu sihir dan yang sepertinya."

Hal senada dinyatakan pula oleh Al Imam Ibn Rajab Hanbali dalam kitabnya Fadhlu Tlmi Salaf 'ala Khalaf bahwa pokok ilmu adalah pengetahuan terhadap Allah subhânahu wa ta'alâ, yang mendatangkan rasa takut dan cinta kepada-Nya, serta selalu mendekat dan rindu kepada-Nya. Selanjutnya adalalah pengetahuan tentang hukum-hukum Allah Ta'ala dan segala apa yang dicintai dan diridhai AllahTa'ala dari hamba-Nya berupa perkataan, perbuatan, keadaan mapupun keyakinan. Siapa saja yang terwujud dua ilmu ini pada dirinya, maka ilmunya adalah ilmu yang bermanfaat." ${ }^{10}$

\section{b. Thariqah pengkaderan}

9 Taqiy al-Din Ahmad ibn 'Abd al-Halim Ibn Taimiyah, Majmû' Fatâwa, Tp: Dâr al-Wafâ', 2005, Jilid 10, hlm. 145-146

${ }^{10}$ Ibn Rajab al-Hanbali, Fadh al-'Ilmi Salaf 'ala Khalaf, ta'liq Syaikh Ali Hasan Al Halabi, Arabia: Dâr al-Ammar Urdun, 1985, hlm. 52 
Menurut hemat penulis Cara Nabi dalam mengkader para sahabat dapat dikelompokkan sebagai berikut;

a) Langsung memberikan contoh

Cara ini disebutjuga dengan qudwah (keteladanan). Cara ini sangat efektif untuk memudahkan bagi kader mengikuti apa-apa yang sudah disampaikan. Sebagai contoh, Rasulullah mengajarkan tentang bacaan-bacaan shalat dan tatacaranya melalui banyak hadits. Dalam lima kali sehari rasulullah bertindak langsung menjadi imam shalat bagi para sahabat sehingga teori-teori shalat menjadi mudah untuk dimengerti baik shalat-shalat wajib maupun sunnah. Untuk itulah Rasulullah mengatakan;

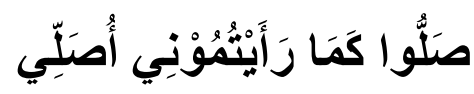

Artinya: "Shalatlah sebagaimana kalian melihat aku shalat." (HR. Bukhari) ${ }^{11}$

Hal demikian terjadi pula pada ibadah-ibadah lainnya seperti haji. Rasulullah bersabda;

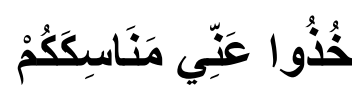

Artinya: "Ambillah dariku tuntunan manasik haji kalian." (HR. Muslim ${ }^{12}$ )

Syaikh Muhammad Abu Al Fattah Al Bayanuni dalam Al Madkhal menyebutkan bahwa cara ini dalam proses da'wah dapat berdampak yang menurut penulis juga memiliki dampak sama dalam pengkaderan dengan beberapa fa'edah ${ }^{13}$;

${ }^{11}$ Abi al Faraj Abdurrahman Ibn Syihabuddin al Bagdadhi, Fath al Bâri, tahqiq: Abu Mu'az Thariq, Saudi Arabia: Dâr Ibn Jauzi, 1422, Jilid 4, hal. 115. Hadits no: 677

12 Diriwayatkan oleh Thabrani, An Nasa' I dan Al Hakim. Lihat, Jalauddin Al Suyuthi, Jâmi' al Ahadîts, Maktabah As Syamilah, Jilid 23, hal. 170

${ }_{13}$ Muhammad Abu Al Fatah Al Bayanuni, Al Madkhal ila 'Ilm Ad Da'wah, Beirut: Mu'assasah Al Risâlah, 1995, hal. 273 
1. Mudah berpindahkan kebaikan dari yang ditiru kepada yang menirunya

2. Bebas mengambil dan terjamin kesahihannya terutama dalam hal-hal yang memerlukan kedetailan.

3. Dalamnya pengaruh bagi jiwa manusia dengan contoh yang langsung dari pada dalam bentuk teori.

Ketiga hal dalam proses pengkaderan juga berlaku. Keteladanan secara signifikan mampu membangkitkan untuk meniru dan mencontoh apa yang diteladankan.

b) Memberikan materi secara bertahap

Dalam proses pengekaderan, materi-materi keislaman tidak langsung beliau sampaikan secara menyeluruh dalam satu waktu. Ini yang disebut pula dengan tahapan penerapan syari'at. Sebagai contoh, perintah Allah untuk berjihad dengan peperangan (qital) baru beliau laksanakan secara konkrit dan jelas ka'idah-ka'idahnya ketika beliau berada di Madinah meskipun istilah jihad sudah disampaikan pada saat periode Makkah seperti pada ayat berikut;

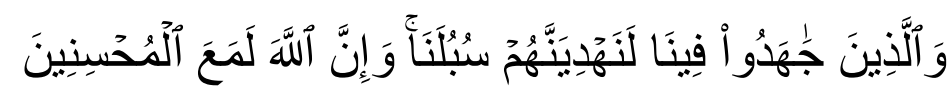

Artinya: "Dan orang-orang yang berjibad untuk (mencari keridhaan) Kami, benar-benar akan Kami tunjukkean kepada mereka jalan-jalan kami. dan Sesunggubnya Allab benar-benar beserta orang-orang yang berbuat baik." (QS. Al Ankabut: 69)

Sebagaimana penjelasan para ulama' tafsir, Ayat ini turun di Makkah meskipun memerintahkan untuk berjihad. ${ }^{14}$

c) Memberikan pengarahan secara mendalam

Nabi dalam banyak sabdanya kepada para sahabat terkadang tampil dengan suara meninggi, seolah-olah hendak marah, atau bahkan hingga meneteskan air mata. Dalam segi-segi ini, Nabi selain merasakan langsung pengaruh wahyu yang turun kepadanya, beliau ingin pula para sahabat merasakan apa yang belaiu rasakan. Salah

${ }^{14}$ Abu Muhammad bin Al Husain bin Mas'ud Al Baghawi, Ma âlim al Tanzîl fì Tafsîr al Qur'ân, tahqiq, Abd Al Razzaq al Mahdi, Beirut: Dâr Ihya' Al Turats al Arabi, 2009, Jilid 3, hal. 549 
satunya adalah ketika menjelaskan perkara penting untuk memegang teguh sunnah Rasulullah.

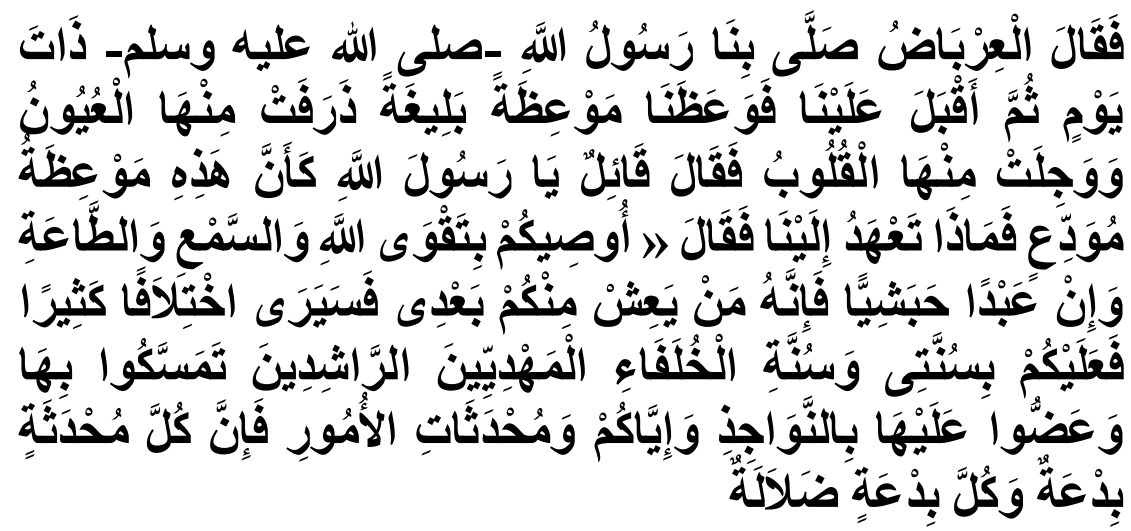

Artinya: "Maka berkata sahabat Irbad bin Sariyah radhiyallâbu'anbu bahwa suatu hati Rasulullah shalat bersama kami. Seusai shalat beliau menghadap kepada kami dan memberikan nasibat dengan nasibat yang begitu dalam sehingga menyebabkan mata-mata (para sahabat) meneteskan air mata, dan membuat hati bergetar. Maka Ibrad berkara kepada Rasulullah; Ya Rasulullah, Nasibat ini seperti sebuah nasihat perpisahan, maka apa yang akan engkau wasiatkan kepada kami wahai Rasulullah. Rasulullah kemudian bersabda: Aku wasiatkan kalian agar bertaqwa kepada Allah. Lalu mendengar dan taat kepada pemimpin, walaupun ia dari kalangan budak Habasyah. Sunggub orang yang hidup sepeninggalku akan melihat perselisiban yang banyak. Maka jaubilah oleh kalian perkara-perkara baru dalam agama kerena hal itu adalah kesesatan. Maka barang siapa yang melibat hal itu diantara kalian, maka wajib bagi kalian untuk mengikuti sunnnabku dan sunnah khulafa ar raasyidin yang mereka telah diberi petunjuk. Berpegang tegublah dan gigitlab ia dengan gigi geraham. Serta jaubilah perkara yang diadaadakan, karena ia adalah bid'ah dan setiap bid'ab itu sesat" (HR. At Tirmidzi dan Abu Dawud disahihkan oleh Al Bani ${ }^{15}$ )

d) Mendelegasikan untuk tugas-tugas khusus

Dalam berda'wah Rasulullah tidak menangani sendiri penduduk-penduduk negeri yang letaknya jauh dari kota Madinah. Rasulullah mengkader para sahabat untuk terjun langsung ke medan

15 Muhammad Nashiruddin Al Al Bani, Al Silsilah Al Sahîhah, Riyadh: Maktabah Al Ma'arif, tt, Jilid 6, hal. 238 dengan nomor hadits. 2735. 
da'wah setelah mendapatkan bekal ilmu dari Rasulullah. Salah satunya sebagaimana pengutusan sahabat Mu'az bin Jabal radhiyallâbu'anbu ke daerah Yaman. Dimana Nabi bersabda;

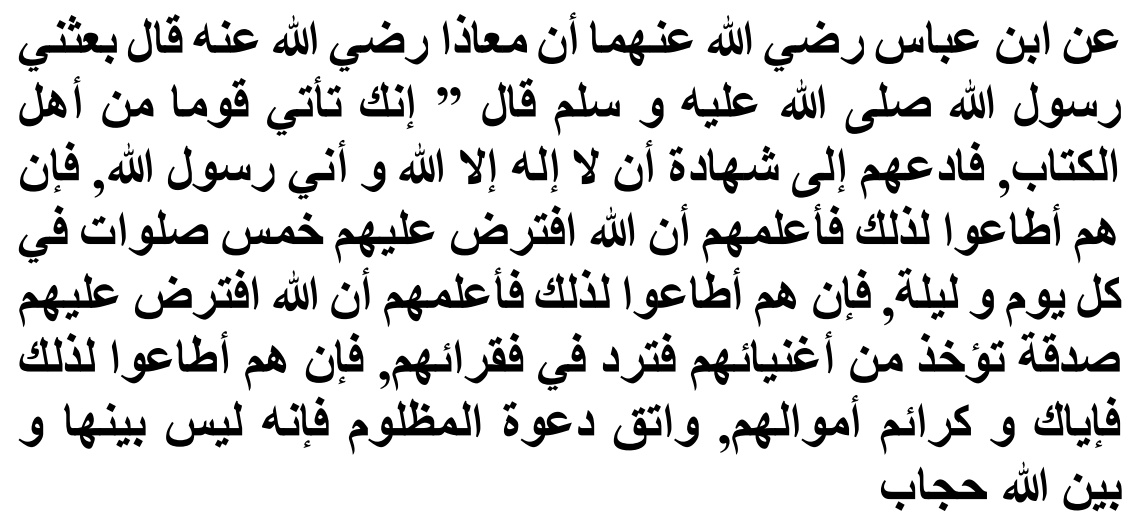

Artinya: Dari sababat Ibnu Abbas radhiyallâbu'anbuma, babwasannya Mu'az, radbiyallâbu'anhu berkata; Rasulullah mengutus aku dan beliau berkata; Sesunggubnya engkau akan mendatangi suatu kaum dari kalangan Abli Kitab; maka hendaklah hal pertama yang engkau dakwahi/ ajak mereka kepadanya (adalab) agar bersyahadat bahwa tiada ilah yang berbake disembah melainkan Allah dan aku adalah utusan Allah, apabila mereka mentaati maka sampaikan kepada mereka bahwa Allah telah memfardukan kepada mereka shalat lima waktu dalam sehari semalam, apabila mereka menaati maka sampaikan kepada merka bahwa Allah telah mewajibkan kepada mereka untuk bersedekah yang diambil dari orang-orang kaya mereka dan diperuntukean kepada orang-orang faqir diantara mereka. Jika mereka menaatiny a maka jaubilah olebmu barta-barta mereka dan takutlah engkau dengan do'anya orang-orang terzhalimi karena tidak ada bijab antara dia dengan Allab (do'anya mustajab)." (HR. Muslim) ${ }^{16}$

Rasulullah melakukan bentuk pendelegasian lainnya dalam beberapa hal seperti; menjadi informan (mata-mata) ketika sebuah peperangan akan berlangsung, memberikan bendera kepemimpinan dalam perang, memberikan mandat kepemimpinan sementara pemerintahan pusat ketika beliau berangkat untuk berperang atau pergi kesuatu tempat, mengutus para sahabat untuk bernegosiasi atau

${ }^{16}$ Imam Muslim, Sahîh Muslim, tarqim; Abdul Baqi, Maktabah Al Syâmilah, Jilid 1, hal. 50 
menyampaikan ajakan Islam kepada negara-negara serta kabilah musyrikin. Semua itu beliau lakukan dalam rangka tathbiq (penerapan) secara langsung teori-teori dan syari'at Islam, serta memberikan amanah kepada para sahabat hingga mereka benar-benar merasakan besarnya tanggungjawab yang diemban.

e) Mengevaluasi sebuah amalan atau pekerjaan

Selain mengajak para sahabat untuk mengevaluasi diri sendiri melalui proses mubasabah, Rasulullah juga mengevaluasi amalan-amalan para sahabat. Jika di dapati ada amalan para sahabat yang kurang tepat sebagaimana yang Rasulullah ajarkan, maka beliau menegur dan memberikan nasihat. Seperti sebuah riwayat yang diceritakan oleh sahabat Al Barra' bin Azib radhiyallâbu'anu yang mendapat teguran Rasulullah perihal do'a (dzikir) yang salah dalam menghafalnya. Suatu ketika Barra' diperintahkan oleh Nabi jika sebelum tidur untuk berwudhu, berbaring ke sisi kanan kemudian berdo'a:

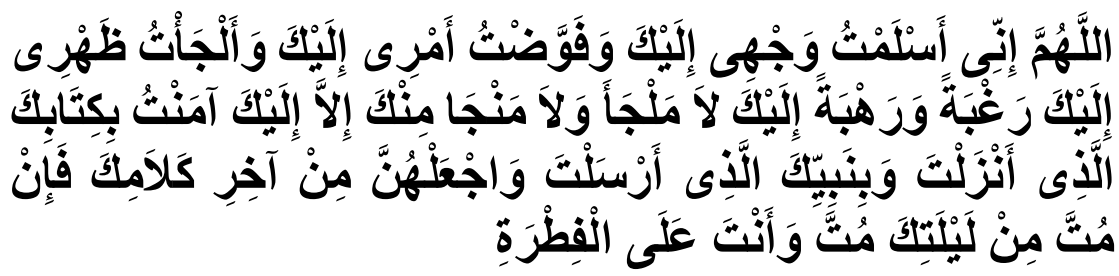

Artinya: "Ya Allah sesunggubnya Aku telah tundukkan wajabku kepadaMu, dan aku serabkan urusanku kepada $M u$, dan aku tundukkan punggungku di hadapan-Mu dengan penub harapan dan rasa takut kepadaMu. Tidak ada tempat berlindung dan tempat menyelamatkan diri dariMu melainkan kepada$M u$, aku beriman kepada kitab yang Engkau telah turunkan dan beriman kepada Nabi yang Engkau telah utus", dan jadikanlah kalimah itu sebagai akbir perkataanmu, jika engkau mati pada malam hari itu, kau mati dalam keadaan fitrah." (HR. Muslim) ${ }^{17}$

Hanya saja, dalam hafalan di depan Nabi Al Barra'

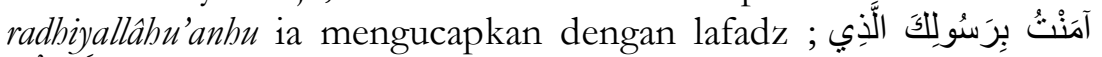
أَرْستَنَّْ Mengetahui hal tersebut, Rasulullah menegur Al Barra' radhiyallâhu'anbu dan memperbaiki hafalannya dengan mengatakan;

${ }^{17}$ Ibid, Jilid 4, hal. 2081. Hadits no: 6710 


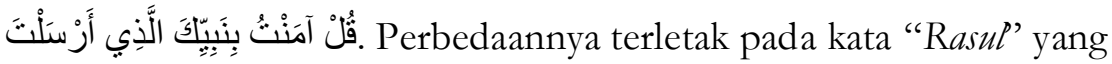
seharusnya "nabiy".

Contoh lainnya adalah manakala Rasulullah mengutus Usamah bin Zaid radbiyallâhu'anbu dan para sahabat lainnya untuk memerangi kaum musyrikin di daerah Huraqah. Ketika itu pasukan kaum muslimin berhasil mengalahkan orang-orang kafir dan membuat mereka bercerai berari. Ketika melihat seseorang dari mereka berupaya melarikan diri, Usamah mengejar dengan salah seorang sahabat Anshar lainnya. Ketika sudah dekat, orang kafir tersebut tiba-tiba mengucapkan syahadat namun Usamah tetap saja membunuh orang tersebut dengan tombaknya. Seusai pulang dari peperangan, berita ini sampai kepada Rasulullah dan beliau menegur Usamah karena telah melanggar etika dalam peperangan dengan sabda beliau: 'Wahai Usamah, apakah engkau membunuhnya setelah dia mengucapkan Lâ ilâha illallâh ?'. Aku menjawab: 'Dia (melakukan itu) untuk melindungi diri (bukan dari hatinya).' Maka Rasulullah terus menerus mengulangi ucapannya sehingga Usamah merasakan sangat bersalah ${ }^{18}$.

f) Melihat situasi dan kondisi objek

Dalam mengkader para sahabat, Rasulullah selalu memperhatikan tentang aspek psikologis, latar belakang, juga situasi serta kondisi yang terjadi pada saat itu. Seperti kasus Abu Dzar Al Ghifari radhiyallahbu'anbu yang meminta amanah kepemimpinan kepada Rasulullah. Rasulullah melarangnya karena mengetahui aspek mental dan kejiwaan yang dimiliki oleh sahabat ini dan bersabda;

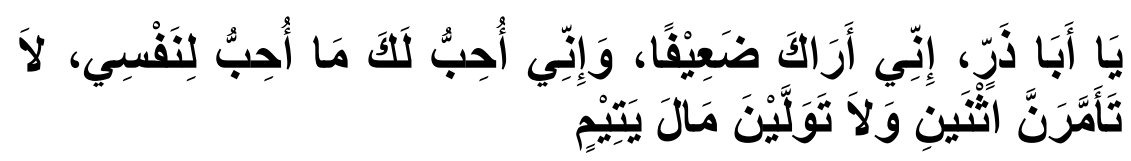

Artinya: "Wahai Abu Dzar, aku memandangmu seorang yang lemah dan aku menyukai untukmu apa yang kusukai untuk diriku. Janganlah sekali-kali

18 HR. Al-Bukhari dalam kitab: Al-Maghâzi, bab: Rasulullah shallallaahu 'alaihi wa sallam- mengutus Usamah bin Yazid ke Kharaqat Bani Juhainah, (no. 4269), dan dalam kitab: ad-Diyaat, bab: Firman Allah subhaanahu wa ta'ala-, "Wa man ahyaahaa." (no. 6872), Muslim dalam kitab: al-Iman, bab: Haram Membunuh Orang Kafir setelah Mengucapkan 'Laa ilaa ha illallahu.' dan Ahmad 
engkau memimpin dua orang1 dan jangan sekali-kali engkau menguasai pengurusan harta anak yatim." (HR. Muslim ${ }^{19}$ )

Demikian halnya ketika Rasulullah menugaskan sahabat Usamah bin Zaid radhiyallâbu'anbu yang berusia masing sangat muda dalam sebuah pertempuran melawan romawi di Syam. Meskipun masih muda, beliau melihat bakat besar yang dimilikinya. Meskipun sejumlah sahabat kurang setuju dengan kepemimpinan Zaid, keputusan untuk memberangkatkan pasukan yang dipimpin oleh Usamah tidak beliau rubah. Bahkan apa yang beliau pilih merupakan pilihan terbaik sehingga Usamah meraik kemenangan gilang gemilang diusianya yang belum genap 20 tahun. $^{20}$

Cara-cara Rasulullah dalam mengkader para sahabat di atas menurut penulis belum sepenuhnya dapat diungkapkan. Jika diteliti lebih lanjut, akan dapat ditarik kesimpulan-kesimpulan lian yang mungkin lebih banyak dan dapat menambah perbendaharaan. Beberapa hal yang belum penulis sebutkan di sini diantaranya;

1. Rasulullah melakukan reward (penghargaan) ketika seseorang sahabat berhasil dalam tugasnya atau menunjukkan komitmen yang tinggi dalam merealisasikan ajaran Islam, dan tidak lupa pula beliau memberikan punishment (hukuman) ketika terjadi pelanggaran terhadap ketetapan yang seharusnya dijalankan oleh para sahabat semisal; jihad dan lain-lain.

2. Rasulullah memberikan perhatian yang dalam dengan memberikan sokongan berupa do'a-do'a mustajab yang beliau panjatkan dalam berbagai kondisi dan situasi dimana kader-kadernya berada.

3. Dalam proses pengkaderan, terkadang beliau menampakkan keburukan seseorang agar para sahabat tidak menirunya, namun suatu waktu beliau menutupi keburukan seseorang (munafik) agar kemaslahatan di tengah-tengah kaum muslimin tetap terjaga.

${ }^{19}$ Imam Muslim, Sahîh Muslim, Jilid 4, hal. 1457. Hadits No. 1826

${ }^{20}$ Abdurrahman Ra'fat Basya, Shuwaru min Hayâti ash ashahâbah, hal. 222-229. Penuls merujuk kepada kitab-kitab berikut; Jâmi' al Ushûl, Jilid 10, hal. 27, Al Ishâbah, Jilid 1, hal. 57, Taqrîb Al Tahdzîb, Jilid 1, hal. 53, Târîkh al Islâm li Adz Zhahabi, Jilid 2, hal. 270-272, dll 


\section{B. Hasil Pengkaderan Rasulullah}

Dengan berbagai bentuk pengkaderan yang dilakukan oleh Rasulullah di atas, maka tampillah kader-kader beliau yang namanya mampu membuat harum sejarah. Berikut ini penulis mencoba untuk menguraikan kepribadian para sahabat setelah bersentuhan langsung dengan pengkaderan yang dilakukan oleh beliau.

\section{a) Memiliki ketahanan dan kesabaran dalam berbagai macam penyiksaan oleh orang-orang kafir.}

Para sahabat adalah manusia mulia yang mendapatkan tempaan iman dari apa yang disampaikan oleh Rasulullah. Keimanan itu begitu kuat menghunjam dalam jiwanya sehingga tidak goyah dalam berbagai siksaan orang-orang kafir. Syaikh Safiyurrahman dalam kitab Ar Rahîq al Makhtûm mengisahkan sebagian bentuk penyiksaan kepada para sahabat yang dilakukan oleh orang-orang kafir Quraisy pada periode dakwah makkiyah diantaranya; ${ }^{21}$

1. Utsman bin Affan radbiyallâbu'anbu pernah digulung ke dalam tikar pelepah kurma oleh pamannya sendiri kemudian ia dipanggang di atas asap api. ${ }^{22}$

2. Suhaib bin Sinan ar Rumy radbiyallâhu'anhu pernah disiksa dengan dipukul dan berbagaimacam penyiksaan hingga kehilangan ingatan dan tidak menyadari apa yang ia ucapkan sendiri.

3. Bilal bin Rabah radbiyallâhu'anbu pernah diikat lehernya dengan tali kemudian diserahkan kepada anak-anak orang kafir untuk diseret-seret dan dibawa berkeliling sepanjang perbukitan di Makkah sehingga lehernya membekas goresan tali. Ia hampir tak pernah putus mendapatkan siksaan dari tuannya Umayyah dengan cara diikat dan dipukuli dengan tongkat, disiksa dibawah terik sinar matahari, kelaparan dan kehausan, dan puncaknya ia dilembar ketanah panas berbatu kerikil dan ditimpa dengan batu besar yang terbakar oleh terik sinar matahari hingga terasa sangat panas dan

${ }^{21}$ Safiyurraman al Mubarak Furi, Ar Rahiq al Makhtum, Beirut: Dâr Ibzm. 2002, hal. 85

${ }^{22}$ Ibid. Penulis merujuk kepada kitab Rahmah lil 'Alamîn, Jilid 1, hal. 
menyusahkannya untuk bernafas. Bilal menolak untuk menyembah Latta dan Uzza dan selalu mangatakan; Ahad, Ahad (Allah Maha Esa). ${ }^{23}$

4. Yasir radhiyallâhu'anbu disiksa hingga meninggal dunia, demikian pula bersama istrinya Sumayyah yang ditusuk kemaluannya dengan tombak oleh Abu Jahal la'natullâh. ${ }^{24}$

5. Aflah radhiyallâbu'anbu seorang budak dari Bani 'Abdi ad Dar juga pernah dijerembabkan ke tanah yang sangat panas dengan terik matahari, kemudian punggungnya ditindih dengan batu besar hingga tak dapat bergerak. Ia juga pernah diikat kakinya dengan tali, dan diseret ke tanah yang panas dengan terik matahari, kemudian mencekiknya hingga orangorang kafir mengiranya telah mati lalu $\mathrm{Abu}$ Bakar memerdekakan dirinya setelah melihat kondisi itu dihadapannya. ${ }^{25}$

6. Khabbab bin al Aratt radhiyallâbu'anhu disiksa dengan berbagai macam siksaan yang berat. Hingga pada suatu ketika, Khabbab dijambak dengan keras, lehernya ditaik dengan sangat keras kemudian dilembarkan ke dalam api yang membara. Api itupun lama-kelamaan padam oleh lemak yang menetes dari punggung Khabbab. ${ }^{26}$

7. Adapula sahabat Nabi yang dibungkus dengan kulit onta dan sapi kemudian dilemparkan ke atas tanah yang panas oleh terik matahari. Sebagianlagi dipakaikan kepadanya baju besi lantas dilemparkan kepada batu besar yang memanas. ${ }^{27}$

Masih banyak lagi siksaan lainnya yang dihadapi oleh para sahabat namun mereka tetap tegar dalam memperjuangkan Islam.

${ }^{23}$ Ibid, Penulis merujuk kepada kitab Ibnu Hisyam, Jilid I, hal. 317, 318.

${ }^{24}$ Ibid, Penulis merujuk kepada kitab Ibnu Hisyam, Jilid I, hal. 319, 320

${ }^{25}$ Ibid, hal. 86. Penulis merujuk kepada kitab Rahmah lil 'Alamîn, Jilid I, hal. 57, Min I'Jâz at Tanzîl, hal. 53

${ }^{26} \mathrm{Ibid}$, hal. 86. Penulis merujuk kepada kitab Nafs al Mashdar, Jilid I, hal. 57, Talqîh fahuwa Ahlul Atsar, hal. 60

${ }^{27}$ Ibid, hal. 87. Penulis merujuk kepada kitab Rahmah lil 'Alamîn, Jilid I, hal. 58 


\section{b) Mampu bertahan meski dalam kondisi serba kekuarangan dan penderitaan.}

Embargo adalah suatu tindakan penyengsaraan yang secara masalah dapat menimbulkan kerugian sangat besar diberbagai aspek kehidupan. Dalam kehidupan bernegara, embargo yang paling menyakitkan adalah dalam bidang ekonomi dan keamanan. Kondisi ini pulalah yang pernah dihadapi oleh para sahabat. Orang-orang kafir Makkah berkumpuk di kediaman Bani Kinanah yang terletak di Mashib dan bersumpah untuk tidak menikahi, berjual-beli, tidak bergaul (bermu'amalah), memasuki rumah maupun berbicara, kepada mereka dari Bani Hasyim dan Bani Abdul Muthalib sebagai kabilah yang melindungi da'wah Nabi. Perjanjian musyrikin itu dituliskan di sahifah dan digantungkan di rongga Ka'bah. ${ }^{28}$ Hasilnya, seluruh kabilah Bani Hasyim dan Bani Abdul Muthallib baik yang kafir atau yang sudah beriman (kecuali Abu Jahal) mendapatkan perlakuan sebagaimana di atas. Mereka diisolasi di bukit milik Abu Thalib selama kurang lebih tiga tahun lamanya.

Tentu saja, hal ini menimbulkan kesempitan hidup dan kelaparan secara berjamaah. Orang-orang kafir di luar Bani Hasim dan bani Abdul Muthalib menjual harga makanan dengan sangat tinggi sehingga tidak mungkin untuk dapat dibeli, semua bahan makanan diawasi dan hanya sangat sedikit yang dapat lolos dengan cara diam-diam. Penyiksaan dalam bentuk ini tidak juga membuat para sahabat gentar dan berpaling dari agamanya. Bukan hanya pada waktu ini saja para sahabat merasakan kesempitan dan kekurangan ekonomi.

Ketika di Madinah, komunitas ashab as suffah juga mengalami hal yang sama. Mengenai keberadaan komunitas ini, beragama pandangan ulama tentang jumlah penduduknya. Dalam kitab tafsir Babr al- Ulùm Imam Abu al-Laits al-Samarkandi menyebutkan angka 400 penghuni ashab al-suffah. Sementara itu, Imam al-Tsa'labi dalam tafsirnya menyebutkan mereka berjumlah 700 an orang. ${ }^{29}$ Demikian halnya dengan pendapat Qatadah sebagaimana dikutip oleh Imam al-

${ }^{28}$ Menurut Ibnu Qayyim orang yang menulis perjanjian ini adalah Baghid bin Amir bin Hasyim dan Rasulullah mendoakan kebinasaan atasnya sehingga tangannya lumpuh. Lihat, Ibnu Qayyim Al Jauziyah, Zâd al Ma'âd fì Hadyi Khair al 'Ibâd, Beirut: Mu'assasah Ar Risâlah, 1994, Jilid 3, hal. 30

${ }^{29}$ Ahmad bin Muhammad bin Ibrahim Ats Tsa'labi, Al Kasyfu wa al Bayan 'an Tafsir al-Qur'an, Beirut: Daar Ihya' at Turats al Arabi, 2002, Jilid 6, hlm. 166 
Bagawi dalam tafsirnya juga menyebut angka yang sama. ${ }^{30}$ Namun menurut penulis, pendapat yang agakanya lebih mendekatai ketepatan adalah pendapat yang ditahqiq oleh Dr. Akram Dhiya' al-Umari dalam kitabnya As Sîrah An nabawiyah As Shahîhah. Dalam kitab tersebut Al Umari menjelaskan bahwa jumlah penghuni ashab as suffah tidak menentu. Jumlah mereka akan bertambah seiring dengan jumlah delegasi yang datang secara rombongan ke Madinah atau berkurang ketika banyak yang datang. Secara rata-rata jumlah mereka adalah 70 hingga 100 orang. ${ }^{31}$

Komunitas para sahabat penuntut ilmu ini memilki jasa besar dalam pengorbanan jihad dan da'wah Islam. Namun demikian, mereka adalah sekelompok masâkin menjaga kehormatan mereka dengan menahan diri dari sifat meminta-minta sebagaimana kebanyakan orang. Kehidupan mereka yang jauh dari harta dan kenikmatan dunia tidak menyurutkan aktifitas pembelaan terhadap Islam, baik melalui agenda keilmuan maupun yang memeras keringat di medan juang. Para sejarawan Islam menggambarkan mereka sebagai kaum yang bahkan tidak memiliki cukup perlengkapan berpakaian. Mereka tidak memiliki pakaian yang melindungi di saatsaat dingin atau panas tiba. Tidak memiliki mantel (baju tebal), bahkan pakaiannya hanya sanggup menutupi betis atau bahkan hanya mampu menutupi lututnya. ${ }^{32}$ Di Masjid Nabi, mereka tinggal di

${ }^{30}$ Abu Muhammad al-Husain bin Mas'ud bin Muhammad bin al-Fara' al-Baghawi, Ma'âlim at Tanzîl fî Tafsîr al-Qur'an, Beirut: Dâr Ihya at Turats al-Arabi, 1999, Jilid 3, hlm. 188

${ }^{31}$ Dr. Akram Dhiya Al Umari menjelaskan bahwa para sahabat yang ada dalam masjid Nabawi (ashab al-suffah) ini terdiri dari berbagai macam golongan (suku). Mereka yang pertama kali tinggal adalah kaum muslimin yang hijrah dari Makkah ke Madinah (muhajirin). Kaum muhajirin terus berduyunduyun datang terutama setalah perang khandak dimana banyak diantara mereka yang menetap di Madinah. Karena yang pertama kali tinggal adalah kaum muhajirin maka tempat tersebut pernah terkenal dengan sebutan Shuffah $\mathrm{Al}$ Muhajirin. Selain mereka adalah delegasi-delegasi yang akan masuk Islam atau juga bahkan ada dari penduduk Madinah yang dengan tulus ingin menjalankan kehidupan zuhud di masjid Nabawi seperti Ka'ab bin Malik ra, Handhalah bin Abu Amir ra,Haritsah bin Nu'man ra dan lain-lain. Adapun sebagai pemimpin ashab al-suffah ini adalah sahabat senior Abu Hurairah ra. (Lihat, Akram Dhiya' Al Umari, Sirah Nabawiyyah as Shahîhah, Madinah al-Munawwarah: Maktabah al-'Ulum wa al-Hikam, 1993, Jilid 1, hlm. 257-259)

${ }^{32}$ Abu Na'im Ahmad bin Abdillah bin Amad bin Ishaq bin Musa bin Mihran al-Ashbahani, Hilyah al Auliyâ' wa Thabaqat al Ashfiyâ', Beirut: Dâr al-Kitab al-Arabi, 1974, Jilid 1, hlm. 377. 
tempat terbuka sehingga debu-debu menempel di tubuh bercampur dengan keringat. ${ }^{33}$ Makanan mereka sangat sederhana, dimana kurma adalah santapan mereka sehari-hari meski terkadang harus menahan panasnya perut akibat hanya memamah kurma. Beberapa kali terjadi diantara mereka (bahkan pemimpin mereka sendiri yakni Abu Hurairah $\mathrm{ra}^{34}$ ) pingsan akibat menahan lapar yang luar biasa. Namun demikian sekali lagi mereka adalah manusia bermental taqwa dan istiqomah sehingga cobaan demi cobaan dilalui demi tegaknya da'wah Islam.

Di dalam al-Qur'an Allah menggambarkan kondisi mereka dengan gambaran yang sangat mullia sebagaimana yang disebutkan dalam Surat Al Baqarah ayat 273. Allah berfirman;

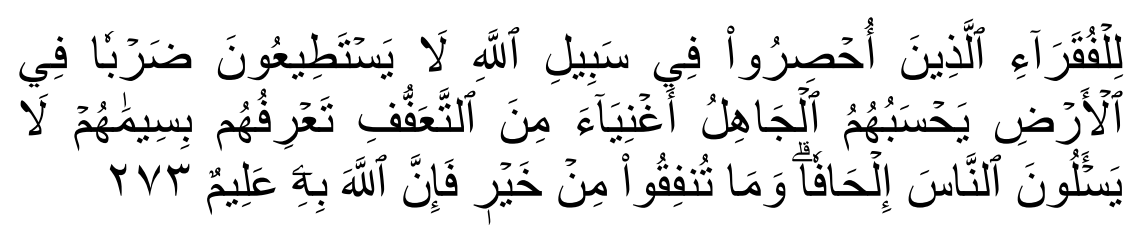

Artinya; (Berinfaqlah) kepada orang-orang fakir yang terikat (oleh jihad) di jalan Allab; mereka tidak dapat (berusaha) di bumi; orang yang tidak tabu menyangka mereka orang Kaya karena memelihara diri dari minta-minta. kamu kenal mereka dengan melibat sifat-sifatnya, mereka tidak meminta kepada orang secara mendesak. dan apa saja harta yang baik yang kamu nafkabkean (di jalan Allah), Maka Sesunggubnya Allah Maha Mengatabui. (QS. Al Baqarah: 273)

Sebagaimana dijelaskan oleh Ibnu Abbas radhiyallâhu'anhu bahwa kata al fuqarẩ dalam ayat ini merujuk kepada komunitas ashab

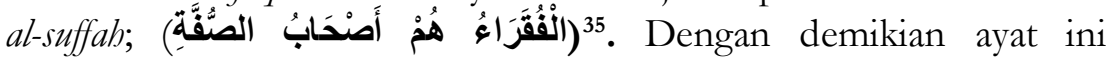
menjelaskan kondisi mereka yang faqir namun disangka sebagai komunitas kaya oleh orang-orang yang jahil karena komunitas ini memelihara diri mereka dari sifat meminta-minta layaknya kebanyakan manusia faqir lainnya. Hal tersebut tentunya sebagai

${ }^{33}$ Ibid., hlm. 341

${ }^{34}$ Abu Hurairah pernah terjatuh diantara mimbar dan kamar Aisyah ra akibat menahan rasa lapar yang sangat.

35 Abu Bakar Muhammad bin Ibrahim bin al-Mundzir al-Naisaburi, Kitâb Tafsîr al-Qur'an, tahqiq. Sa'ad bin Muhammad as Sa'd, Madinah Al Munawarah: Dâr al-Nasyr, 2002, hlm. 42. 
bentuk menjaga kehormatan diri dan kehormatan risalah yang mereka emban. Rasul dan para sahabatnyalah yang justru lebih mengenal mereka berdasarkan sifat-sifat kefakiran mereka (عَلامَةُُ الْفَقْرِ( Dimana kondisi mereka bahkan menjadi perhatian Rasul sehingga memerintahkan kepada para sahabat untuk turut serta memback-up komunitas ini. ${ }^{37}$

Rasulullah sendiri mengambil garda terdepan dalam memberikan perhatian kepada ashab al-suffah ini. Beliau bahkan lebih memperhatikan kondisi mereka jika dibangingkan dengan sanak keluarga beliau mengingat pentingnya komunitas ini. Selain memberikan pertolongan kepada yang sakit, memberikan keseluruhan sedekah tanpa terkecuali, memberikan hadiah dengan bersama turut menikmati, mengundang mereka dalam jamuan makanan jika dirumah beliau terdapat makanaan, memberikan persediaan terakhir keluarga kepada mereka, juga membersamai mereka dalam berdzikir, beribadah, menuntut ilmu dan memberikan nasehat serta wejangan kepada mereka untuk tetap berada di jalan Allah. Perhatian beliau kepada mereka begitu mendalam sampaisampai jika keluarga beliau ada yang mendapatkan kenikmatan, beliau senantiasa mengingat penderitaan yang dialami ashab al-suffah. Hal tersebut sebagaimana ditunjukkan Rasulullah ketika Fathimah ra memeinta pelayan kepada beliau karena beban rumah tangga yang cukup melelahkan. Justru beliau marah dan mengatakan;

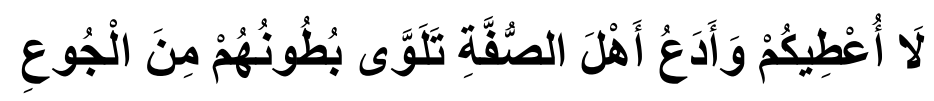

Aku tidak akan meluluskan permintaan kalian, lalu membiarkan para penghuni Suffah itu sama melipatkan perut karena menahan rasa lapar. (HR. Ahmad dari sahabat Ali bin Abi Thalib ra) ${ }^{38}$

${ }^{36}$ Ahmad bin 'Ali Abu Bakar al-Râzi al-Jashsash al-Hanafi, Ahkâm alQur'ân, Beirut: Haya' al-Turats al-Arabi, 1405, Jilid 2, hlm. 180.

${ }^{37}$ Abu Abdillah Muhammad bin Abdillah bin Isa bin Muhammad alMari, Tafsîr al-Qur'an al- 'Aziz li Ibn Abi Zaamanin, Mesir: Maktabah al-Faruq al-Haditsah, 2002, Jilid 1, hlm. 262.

${ }^{38}$ Abu Abdillah Ahmad bin Hanbal, Musnad al-Imam Ahmad bin Hanbal, tahqiq. Syu'aib al-Arnut, Arabia: Mu'assasah al-Risâlah, 2001, Jilid 2, hlm. 34 . 


\section{c) Para sahabat tampil sebagai manusia yang siap berkorban jiwa dan raga dan perindu syahid di jalan Allah}

Para sahabat adalah manusia-manusia yang siap untuk berkorban jiwa dan raga untuk kehidupan abadi yang kekal abadi. Semangat mereka dalam berjihad tidak dapat diuraikan dengan kata-kata. Keberanian mereka dalam medan tempur ibarat harimau yang haus akan darah segar mangsanya. Merekalah para perindu surga melalui syahid di jalan-Nya. Untuk menuliskan kisah-kisah heroik dalam medan Jihad para sahabat, tentunya akan membutuhkan berjilid-jilid buku yang sangat tebal. Namun demikian, penulis akan sebutkan secuil fenomena yang menjadi bukti pengorbanan mereka untuk menjemput syahid.

- Sebagian Kisah dalam perang Mu'tah

Pada perang Mu’tah, kita dapat melihat keberanian luar biasa para sahabat. Peperangan dengan bangsa Romawi ini benar-benar begitu heroik. Pada peperangan ini Rasulullah mengangkat Zaid bin Haritsah radhiyallâbu'anhu sebagai panglima seraya berpesan; Apabila Zaid gugur, maka Ja'far (yang mengambil alib). Jika Ja'far gugur, maka Ibnu Rawahah (yang mengambil alih). ${ }^{39}$ Mereka berangkat dengan 3000 pejuang yang seluruhnya rindu akan syahid. Betapa tidak, mereka tetap tidak gentar meskipun para informan mendapatkan informasi bahwa Kaisar Heraklius telah sampai dengan 100.000 prajurit ditambah lagi 100.000 prajurit dari kabilah-kabilah bangsa Arab yang tunduk dengannya. Dalam kondisi seperti itu, salah seorang sahabat mengusulkan untuk meminta bantuan mujahidin tambahan kepada Rasulullah. Namun sahabat Abdullah ibn Rawahah menolak sambil membangkitkan semangat pasukannya dan berkata;

"Wahai kaum, demi Allah sesungguhnya perkara yang kalian tidak sukai ini adalah perkara yang kamu keluar mencarinya, yaitu syahadah (gugur di medan perang di jalan Allah Subhanabu wa Ta'ala). Kita itu tidak berjuang karena jumlah pasukan atau kekuatan. Kita berjuang untuk agama ini yang Allah Subhanabu wa Ta'ala telah memuliakan kita dengannya. Bergeraklah. Hanya

${ }^{39}$ Muhammad Sa'id Ramadhan Al Buthi, Fiqh Sîrah Al Nabawiyah, Beirut: Dâr Fikr Al Mu'ashir, 1991, hal. 258. Penulis merujuk kepada riwayat sahih Bukhari dan Ahmad serta Ibnu Sa'ad. 
ada salah satu dari dua kebaikan: kemenangan atau gugur (syahid) di medan perang." 40

Mendengar seruan itu, para sahabat yang lain semakin mantap bergerak dan membenarkan perkataan tersebut. Pada peperangan ini, Zaid bin Haritsah radhiyallâhu'anbu selaku panglima gugur dan memanggil Ja'far untuk melanjutkan kepemimpinan. Ja'far radhiyallâbu'anhu maju dengan gagah berani hingga suatu saat pasukan romawi menebas tangan kanannya. Bendera kembali dipegang tangan kirinya, namun dengan cepat tangan kirinya juga tersambar oleh pedang romawi. Belum juga menyerah, Ja'far kemudian memeluk bendera putih pemberian Rasul itu dengan badannya hingga tertebas pula badannya menjadi dua bagian hingga beliaupun syahid. Kepemimpinan perang yang terus berkecamuk dengan jumlah tidak seimbang itu dipegang oleh Abdullah bin Rawahah radbiyallâbu'anbu hingga beliaupun syahid ${ }^{41}$. Dalam peperangan selanjutnya sahabat Khalid bin Walid radbiyallâbu'anbu di daulat oleh para sahabat untuk melanjutkan jihad dengan penuh pengorbanan sehingga membuat kekalahan di pihak musuh secara bertahap. Dalam perang Mu'tah ini, kaum muslimin gugur sebagai syuhada sangat banyak. Mereka telah berperang tanpa rasa takut meski pasukan musuh sedemikian besar menggempur kaum muslimin.

- Sepenggal kisah perang uhud

Peristiwa perang Uhud banyak mengisahkan pahlawan-pahlawan perang yang berani mati dan cinta syahid. Di dalamnya adalah salah seorang sahabat Nabi yang bernama Handzalah bin Abu Amir radhiyallâhu'anbu. Dialah pemuda yang ketika pasukan Uhud bergerak ke medan tempur, ia sedang baru saja menikah. Maka berbulanmadulah kedua pasangan syurga itu sebagai layaknya suami istri. Belum sempat pemuda itu mandi junub, ia mendengar kaum

${ }^{40}$ Ibid, hal. 259

${ }^{41}$ Ketika perang berkecamuk, rasulullah mendapatkan wahyu dari Allah tentang kondisi peperangan. Setelah mengetahui syahidnya ketiga panglima beliau, Rasulullah menceritakan kepada para sahabat lainnya sambil meneteskan air mata. (HR. Bukhari No: 4262). Dalam sahih bukhari terdapat hadits-hadits yang mengisahkan perang mu'tah ini dalam bab Ghazwati Mu'tah min Ardhi Syam. Lihat. Muhammad ibn Isma'il Ibn Ibrahim Ibn al Mughirah al Bukhari, Al Jâmi' al Musnad al Shahîh al Mukhtashar min Umûr Rasulillâh, tahqiq: Muhammad Zuhair ibn Nashir al Nashir, Tt: Dâr Thauq An Najâh, 2001, Jilid 5, hal. 143 
muslimin sedang bergerak ke medan laga. Lantas ia tinggalkan istrinya seketika dan berangkat menyongsong jihad di bukit Uhud. Pada pertempuran yang amat sengit itu, Handzalah syahid sebagai syuhada setelah tubuhnya roboh ditangan kafir Syaddad bin Al Aswad. Rasulullah kagum melihat semangat Handzalah dan mengatakan kepada para sahabat; "Sesungguhnya sahabat kalian, Handzalah, pasti akan dimandikan malaikat." 42

Pada perang ini pula, ketika kaum muslimin terjepit dan pasukan musuh semakin dekat kepada Rasulullah, Rasulullah lantas memanggil para sahabatnya yang sedang sibuk melayani duel orangorang kafir; "Siapa orang yang siap berkorbannyawa untuk kami.!" Maka sahabat Ziyad bin As Sakan radhiyallâbu'anbu datang bersama lima sahabat Anshar yang lian guna melindungi Rasulullah. Pada saat itu, para pecinta syahid itupun gugur satu demi satu dan yang terakhir Ziyad bin As Sakan dalam kondisi terluka sangat parah. Setelah Rasulullah berhasil dilindungi oleh para sahabat yang lain, beliau kemudian menuju kepada Ziyad yang masih tak berdaya dan menunggu kematiannya. Rasulullah merebahkan tubuh Ziyad di atas pangkuannya. Di atas paha Rasulullah itulah Ziyad radhiyallâhu'anbu kemudian menghembuskan nafas terakhir sebagai syahid. ${ }^{43}$

- Sepenggal kisah sahabat Al Barra' bin Malik radbiyallâhu'anbu

Dr. Abdurrahman Rafat Basya mengisahkan kepahlawanan dan keberanian sahabat Al Barra' dalam bukunya yang berjudul Shuwaru min Hayatish Shahâbah. Dilah pemuda berperawakan kurus namun bernyali baja dan kuat. Medan jihad yang pernah dilaluinya bersama Rasulullah telah membuat namanya gemilang. Dia pernah membunuh 100 orang sendirian dalam duel satu lawan satu di medan laga sebelum perang berkecamuk. Jika ditambah dengan jumlah di dalam peperangan, tentu akan sangat sulit menebak jumlah orangorang kafir yang mati di tangannya. Salah satu peristiwa menarik yang pernah dilaluinya adalah ketika ia bergabung dalam pasukan Khalid bin Walid radhiyallâhu'anbu ketika mendapat perintah Khalifah Abu Bakar radhiyallâbu'anbu untuk meredam pemberontakan Nabi palsu Musailamah dan para murtaddin (orang-orang murtad) yang berjumlah 40.000 orang pendukung dari berbagai kabilah. Abu Bakar mengutus Khalid setelah batalyon pertama yang dikirim Abu Bakar berhasil

42 Ibnu Ishaq, As Sîrah An Nabawiyah, tahqiq, Ibn Hisyam, terj. Jakarta: Pustaka Akbarmedia, 2012, hal. 496

${ }^{43}$ Ibid, hal. 496 
dikalahkan oleh Musailamah. Ketika perang berkecamuk dengan sangat sengit dan pasukan Muasilamah tanpak unggul maka Barra' berkata kepada kaumnya; "Wahai orang-orang Anshar, jangan ada salah seorang dari kalian yang berpikir untuk pulang ke Madinah, tidak ada Madinah bagi kalian setelah hari ini. Yang ada hanyalah Allah semata dan mati syahid." Ketika Musailamah terdesak, pasukan Musailamah masuk ke benteng yang tinggi dan berlindung di dalamnya. Benteng yang kokoh dan tinggi tidak dapat ditembus oleh pasukan Khalid. Maka tampillah Al Barra' meminta untuk dilemparkan ke dalam benteng sendirian. Di dalam benteng ribuan tentara Musailamah telah menanti. Dengan berani dan beringas $\mathrm{Al}$ Barra' berhasil menumbangkan sepuluh orang kafir di depan pintu benteng lalu membuka pintunya. Pada saat itu, 80 luka tusuk dan sayatan menjadi hiasan tubuhnya. Dengan terbukanya pintu benteng, maka matilah Musailamah dan sejumlah besar pengikutnya. Kerinduannya untuk syahid dijawab oleh Allah dalam perang penaklukkan Tustar di negeri Persia. ${ }^{44}$

- Anak-anak yang ikut berjihad

Anak-anak yang telah masuk Islam pada masa Nabi turut menjadi pelindung dalam Jihad. Semangat Jihad yang dikobarkan Nabi telah pula merasuk kedalam jiwa-jiwa mereka yang bersih. Salah satu kisah dari sekian kisah yang ada, penulis akan sebutkan dua sahabat Nabi; Umair bin Abi Waqqas dan saudaranya Sa'ad bin Abi Waqqas radhiyallâhu'anbuma. Pada saat perang Badar Kubra bermula, mereka berdua secara diam-diam turut serta dalam pasukan. Mereka begitu ingin bertemu syahid. Mereka bersembunyi dari pengelihatan rasul karena takut kalau-kalau tidak mendapatkan izin. Maka tak kala Rasulullah mendapati mereka, Rasulullah tidak memberikan izin karena mereka masih anak-anak. Umair menangis tersedu-sedu meminta belas kasih Rasulullah untuk turut berkorban dalam jihad. Rasulullahpun tesentuh dan pada akhirnya memberikan izin. Betapa cerahnya kedua wajah pemuda mulia ini mendengar izin Rasulullah. Sa'adpun menyematkan pengikat pedangnya di pundak Umair karena dia masuh kecil. Maka tibalah saat yang dijanjikan Allah, Umair syahid dalam medan tempur. Ia anak berjuwa besar meski untuk mengangkat sebilah pedangpun ia belum terlalu kuat ${ }^{45}$.

44 Abdurrahman Ra'fat Basya, Shuwaru min Hayâti ash ashahâbah, Beirut: Dâr An Nafâ'is, 1992, hal. 40-46

${ }^{45}$ Ibid, hal. 289 
Pada tulisan yang terbatas ini, tentu saja penulis tidak dapat menyebutkan secara menyeluruh heroisme jihad di jalan Allah yang pernah terjadi pada masa sahabat. Cukuplah sejarah di atas menjadi catatan untuk kita semua bahwa pengkaderan Nabi mampu menumbuhkan semangat Jihad luar biasa.

\section{d) Para sahabat adalam tampil sebagai manusia yang sangat jauh dari cinta dunia.}

Para sahabat Nabi memiliki hati yang terikat dengan akhirat dan tidak memiliki kecintaan terhadap duniawi. Segala sesuatu yang mereka upayakan dalam konteks kehidupan duniawi dilakukan dalam rangka mendekatkan diri kepada Allah semata-mata. Kekayaan yang mereka miliki bukanlah kekayaan yang mereka habiskan untuk melayani selera hati dan keperluan diri pribadi dan keluarga. Kekayaan itu mereka pergunakan untuk kemajuan Islam dan kaum muslimin. Sebagai contoh adalag sahabat Abu Bakar As Shiddiq radhiyallâhu'anbu. Dialah Khalifah pengganti Rasulullah setelah beliau wafat. Dialah manusia yang pernah dido'akan oleh Rasulullah dengan do'a; (Ya Allah, sertakanlah Abu Bakar bersamaku dengan derajat yang sama pada hari kiamat $)^{46}$. Pemimpin umat Islam yang ahli zuhud ini ketika meninggal dunia tidak meninggalkan uang meski satu dinar atau satu dirhampun. ${ }^{47}$ Padahal beliau adalah Khalifah bagi negara Islam ketika itu. Seluruhnya beliau berikan ke baitul mall untuk kepentingan kaum muslimin. Ketika Rasulullah masih hidup beliaulah penyumbang dana terbesar sehingga mampu untuk tidak menyisakan sedikitpun untuk keluarganya demi Islam.

Sahabat mulia lainnya seperti Umar bin Khattab radhiyallâhu'anbu. Beliau adalah manusia tegas namun sangat banyak melalui hari-harinya dengan menangis dihadapan Allah. ${ }^{48}$ Dialah

${ }^{46}$ Abdurrahman bin Ali bin Muhammad bin al Faraj Ibnul Jauzi, Sifat As Safwah, Beirut: Dâr al Ma'arif, 1979, Jilid I, hal. 240. Teks do'anya sebagai berikut:

${ }^{47}$ Kanzul Ummal, Jilid 3, hal. 132

$$
\text { اللهم اجعل أبا بكر معي في درجتي يوم القيامة }
$$

${ }^{48}$ Dalam riwayat Abdullah bin Isa radhiyallâhu'anhu ia mengatakan bahwa pada wajah Umar bin Khattab terdapat dua garis hitam (dibawah keduamatanya), karena sering menangis. (Lihat, Muhammad Ahmad Isa, Al 'Asyratu al Mubasyirûn bi al Jannah, terj. Fajar Kurnianto, Jakarta: Pustaka Imam As Syafi'i, 2011, hal. 108. Penulis menukil kitab Shifat as Shafwah, jilid 1, hal. 115 
manusia yang Rasulullah melihat langsung Istana dan pelayan bidadarinya di surga. ${ }^{49}$ Harta yang banyak dimilikinya tidak lantas membuatnya hidup serba berkecukupan. Bahkan ketika ia ditunjuk sebagai khalifah sepeninggal sahabat Abu Bakar, ia hidup sebagai manusia yang zuhud terhadap kehidupan dunia namun mencintai ibadah dan jihad di jalan-Nya. Sebagai contoh Al Hasan radhiyallâbu'anbu pernah berkata bahawa ketika Umar diangkat menjadi Khalifah, beliau pernah berkhutbah di hadapan kaum muslimin dengan sarung yang ia kenakan dalam kondisi ditambal dengan 12 tambalan. Annas radhiyallâbu'anhu juga meriwayatkan bahwa keuda pundak pakaian Umar terdapat tiga tambalan. ${ }^{50}$ Bahkan pada suatu ketika, putrinya Hafsah radhiyallâbu'anba pernah mengusulkan kepada Umar untuk meningkatkan sedikit kualias makanan dan pakaian yang selama ini digunakan. Namun Umar radhiyallâhu'anbu justru mengatakan; "Aku tidak akan pernah menerima saranmu. Tidak ingatkan kamu akan kesulitan hidup yang dijalani Rasulullah, begitu pula Abu Bakar ?". Umar radhiyallâbu'anbu terus-terus mengatakan hal itu sehingga membuat Hafsah menangis dan bersedih. Umar radhiyallâbu'anbu lantas berkata kepada putrinya itu; "Demi Allah, aku benar-benar akan mengikuti cara hidup mereka yang berat. Semoga saja, aku mendapat keridhaan Allah dan meneladani mereka." ${ }^{51}$

${ }^{49}$ Sebagaimana yang diriwayatkan oleh $\mathrm{Al}$ Bukhari sebagai berikut:

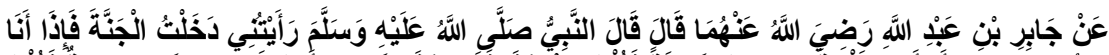

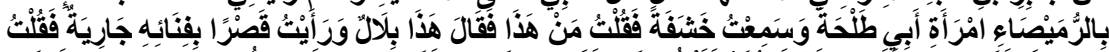

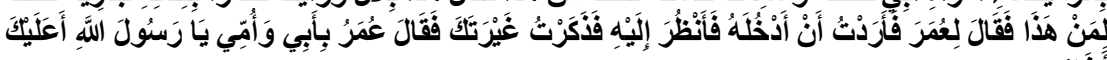

Dari Jabir bin Abdillah radhiyallâhu'anhuma berkata; berkata Nabi shallallâhhu'alaihi wasallam; "Sewaktu tidur aku bermimpi seakan-akan berada di syurga. Kemudian aku melihat seorang wanita sedang berwudhu disebelah istana, maka aku bertanya; Milik siapa istana ini ? ia menjawab; milik Umar. Maka aku teringat kecemburuan Umar, dan segera aku menjauhi istana itu." Sambil menangis Umar berkata; Demi Allah, mana mungkin aku cemburu padamu wahai Rasulullah." (HR. Bukhari, No: 3679) Lihat, Muhammad ibn Isma'il Ibn Ibrahim Ibn al Mughirah al Bukhari, Al Jâmi' al Musnad al Shahîh al Mukhtashar min Umûr Rasulillâh, Jilid 5, hal. 10

${ }^{50} \mathrm{Ibid}$, hal. 107

${ }^{51}$ Ibid, hal. 108. Penulis mengutip dari kitab Shifat as Shafwah, Jilid 1, hal. 115 
Demikianhalnya dengan sahabat-sahabat Nabi yang lain, mereka sangat menjauhi kesenangan duniawi, mereka lebih senang berjihad, beribadah, berda'wah dan menyegerakan amal-amal kebajikan. Mereka tidak lalai dengan keadaan dunia yang berada di dalam genggaman tangannya, bahkan mereka rela melepasnya meskipun berjumlah amat sangat banyak. Utsman bin Affan, Ali bin Abi Thalib, Abdurrahman bin 'Auf, Talhah bin Ubaidillah, Zubair bin Awwam, Mu'awiyah bin Abi Sufyan, Abu Dzar Al Ghifari, radhiyallâbu'anbum ajma'în dan lain-lain adalah manusia-manusia negeri akhirat yang berhasil ditempa langsung oleh Baginda Rasul dalam mensikapi duniawi ini.

\section{e) Para sahabat adalah kader dalam menguasai ilmu syari'ah}

Dalam proses kaderiasai Rasulullah ilmu merupakan hal terpenting. Ilmu yang dimaksud di sini adalah ilmu syari'ah atau ilmu yang berasal dari wahyu Ilahi. Aktifitas Rasulullah dalam penyampaian ilmu sudah dimulai sejak da'wah beliau di Makkah melalui rumah Darul Arqam. Di tempat inilah beliau menyampaikan syari'at Islam secara sembunyi-sembunyi dan bertahap untuk kemudian di amalkan oleh para sahabat. Dalam prosesnya Rasulullah adalah garda terdepan dalam meberikan qudwah hasanah dari setiap apa yang beliau sampaikan.

Di madinah, komunitas pegiat ilmu secara khusus beliau sediakan bagi mereka yang mewakafkan diri untuk bertakhassus (spesialisasi) dalam kelompok sahabat Ashab As Suffah dimana perhatian beliu terhadap komunitas ini sangat tinggi. Melalui madrasah inilah Rasulullah memiliki kader-kader penghafal al Qur'an, penghafal hadits, sekaligus kader-kader yang memiliki kemampuan dalam tulis menulis. Dr. Akram Al-Umari menyebutkan, bahwa aktifitas keseharian ashab al-suffah ini tertumpu pada kegiatan thalab al'ilmi (menuntut ilmu), beribadah dan bertaqarrub kepada Allah dengan senantiasa beri'tikaf di masjid, serta berjihad di jalan Allah. Aktifitas keilmuan yang menonjol itu menghantarkan penghuninya sebagai para ahli ilmu di kalangan para sahabat dan disegani. Abu Hurairah ra misalnya, dimana beliau menghafal dan meriwayatkan 5374 hadits-hadits yang dicatat dan didengar langsung dari $\mathrm{Nabi}^{52}$. Abdullah bin Mas'ud ra juga terkenal pakar dalam bidang tafsir al-

${ }^{52}$ Muhammad bin Shalih al-Utsaimin, Musthalah al-Hadits, Mesir: Maktabah al-'Ulum, 1994, hlm. 34. 
Qur'an, Hudzaifah IbnYaman ra selaku pakar hadits-hadits fitan dan penyimpan data-data munafiqin, Ubadah bin As Shamit ra juga pakar dalam al-Qur'an dan tulis menulis sehingga busur yang dimiliknya ia hadiahkan kepada sahabat lain karena kesibukannya di bidang itu. ${ }^{53}$ Mereka yang dibina di dalam majelis Rasulullah ini selain menimba ilmu secara intens juga melihat secara langsung bagaiamana Nabi menyelesaikan problematika keummatan. Keberadaan mereka selain memberi sokongan terhadap gerakan da'wah secara keilmuan, juga memberikan kekuatan besar dalam futuhat dakwah Islam. Bahkan sebahagian mereka termasuk gugur di medan tempur. Seperti dalam perang Badar, gugur sejumlah syuhada' dari ashab al-suffah seperti; Shafwan bin Baidha, Khuraim bin Fatik Al Asadi, Khabbib bin Yasaf , Salim bin Umair dan Haritsah bin Nu'man radhiyallâbu'anbum. Ada pula yang gugur sebagai syuhada Uhud seperti Handzalah radbiyallâbu'anbu dengan julukan al Ghasil (jenazah yang dimandikan oleh Malaikat) ${ }^{54}$, ada yang gugur dalam perang Hudaibiyah seperti Jarhud bin Khuwailid dan Abu Sarihah al-Ghifari radhiyallâbu'anbuma, dan sejumlah peperangan lainnya seperti perang Tabuk, Khiabar dan Yamamah.

Selain mereka kader-kader Nabi dalam ilmu juga dimiliki oleh sahabat lainnya seperti Abu Bakar As Shiddiq, Anas bin Malik, Ibn Mas'ud, Ibn Abbas, Umar bin Khattab Utsman bin Affan, Ali bin Abi Thalib, Aisyah, Hafsah, Ummu Salamah, dan lain-lain radhiyallâbu'anbum. Selain sebagai rujukan para tabi'in, mereka juga menjadi rujukan pula bagai sahabat-sahabat lainnya.

\section{f) Para sahabat adalah generasi pemilik Akhlak mulia}

Hasil dari proses pengkaderan lainnya di masa Rasulullah adalah merubah masyarakat Arab yang sebelumnya jahiliyah dan jauh dari akhlak yang mulia menjadi manusia-manusia agung tanpa

${ }^{53}$ Akram Dhiya' Al Umari, Sîrah Nabawiyyah al -Shahîhah, Jilid 1, hlm. 264. Al Umari merujuk data tersebut dalam Sunan Abu Dawud jilid 3, hlm. 234 dan Sunan Ibnu Majjah jilid 2, hlm. 730

${ }^{54}$ Ahmad Ahmad Ghalus, As Sirrah an Nabwiyah wa al-Da'wah fì al'Ahdi al-Madani, Saudi Arabia: Mu'assasah al-Risâlah, 2004, hlm. 342. Lihat pula, Abdul Malik bin Hisyam bin Ayub Al Humairi, As Sîrah al-Nabawiyah li Ibn Hisyam, tahqiq. Mustafa As Siqa', Mesir: Syirkah Maktabah wa Mathba' Musthafa al-Baabi al-Halabi, 1955, Jilid 2, hlm. 207. 
tanding. Salah satu akhlak mulia pada masa Nabi adalah itsar (yaitu; mendahulukan sesama muslim meski dirinya sendiri memerlukan).

Salah satu contoh itsar di masa sahabat adalah ketika Nabi dan para sahabat muhajirin Makkah hijrah ke Madinah, penduduk muslim Madinah (kaum Anshar) menerima kedatangan beliau dan saudarasaudar mereka seiman dengan penuh penghormatan, lemah lembut dan kasih sayang. Mereka memebrikan apa yang mereka miliki, menjamu, membantu merintis hidup di kota yang baru dan lain-lain. Mereka bahkan siap memberikan dan menolong kaum muhajirin meskipun sesungguhnya mereka sendiri (kaum Anshar) membutuhkannya. Dalam tafsir Ibnu Katsir rabimabullâh beliau menyebutkan sebuah riwayat Al Bukhari yang menyebabkan Allah menurukan ayat tentang itsarnya kaum Anshar tersebut. ${ }^{55}$ Imam AlBukhari meriwayatkan bahwa Rasulullah Shallallâhu 'alaibi wa sallam mendapatkan tamu, namun keluarganya tidak mempunyai makanan sedikit pun. Kemudian salah seorang dari kaum Anshar menemui beliau, lantas pergi membawa tamu tersebut ke rumahnya. Di rumahnya, sahabat dari kaum Anshar tersebut menyuguhkan hidangan ke hadapan tamunya, dan menyuruh istrinya mematikan lampu. la menggerak-gerakkan tangannya seperti orang makan, padahal ia tidak memakan makanan sedikit pun, hingga tamunya memakan habis hidangannya. la berbuat itsar kepada tamunya atas dirinya sendiri, dan keluarganya. Keesokan harinya, Rasulullah bersabda kepada sahabat dari kaum Anshar tersebut, "Sungguh Allah takjub dengan penghormatanmu terhadap tamumu tadi malam. " Kemudian turunlah ayat;

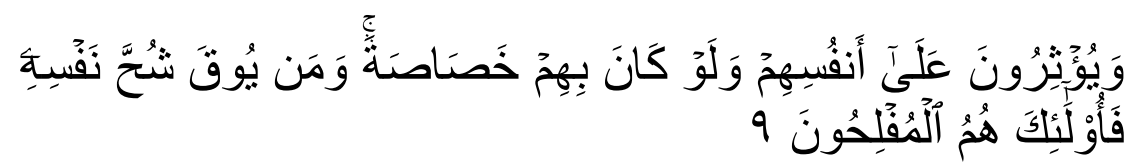

"Dan mereka mengutamakan (orang-orang Mubajirin) atas diri mereka sendiri, sekalipun mereka memerlukan (apayang mereka berikan itu). Dan barangsiapa dipelihara dari kekikiran dirinya, mereka itulah orang-orang yang beruntung. "(QS. Al-Hasyr: 9).

${ }^{55}$ Abu Fida' Isma'il bin 'Umar bin Katsir, Tafsîr al Qur'ân al Adzhîm, tahqiq; Sami bin Muhammad Salamah, Tp: Dâr at Thîb li An Nasr wa at Tauzî’, 1999, Jilid 8, hal. 71 
Hasil-hasil pengkaderan lainnya tentu masih sangat banyak yang belum penulis jelaskan di sini. Namun demikian beberapa hal diantaraya dapat penulis tambahkan secara garis besar berikut;

1. Para sahabat adalah generasi yang sangat bersemangat dalam beribadah kepada Allah. Mereka berada dihadapan Allah dengan penuh kehinaan hingga melalui malam-malam mereka dengan shalat malam yang panjang.

2. Para sahabat juga generasi yang menjaga betul syari'at yang dibawa oleh Rasulullah. Mereka memahami dan mengamalkannya dengan benar. Tidak ada satupun diantara mereka yang berani merubah-rubah ajaran Islam yang mulia ini.

3. Dalam berda'wah mereka adalah orang-orang yang tidak pernah mengenal lelah. Mereka diutus sampai ke pelosokpelosok negeri untuk membina ummat. Hal itu terlus berlanjut seajan dengan futuhat Islam setelah wafatnya Rasulullah.

4. Mereka adalah generasi yang memiliki kecerdasan dalam memimpin ummat, menjalankan roda pemerintahan dan menegakkan ditengah-tengah masyarakat. Tidak berbuat zhalim, korupsi, kolusi dan nepotisme kekeluargaan. 